\title{
Conservation potential of shade-tolerant forest species in agricultural mosaics in the eastern Brazilian Amazon
}

\author{
Igor DO VALE ${ }^{1}$, Izildinha Souza MIRANDA ${ }^{1, *}$, Danielle MITJA ${ }^{2}$, Alessio Moreira SANTOS ${ }^{3}$, Graciliano \\ Galdino Alves dos SANTOS ${ }^{1}$, Fábio Miranda LEẤ ${ }^{1}$, Mariana Gomes OLIVEIRA ${ }^{1}$, Luiz Gonzaga da Silva COSTA \\ Universidade Federal Rural da Amazônia, Programa de Pós-Graduação em Ciências, Florestais, Av. Tancredo Neves 2501, Caixa Postal 917, 66077-570 Belém, Pará, Brazil \\ 2 Institut de Recherche pour le Développement, UMR 228 ESPACE-DEV, Maison de la Télédétection, 500 rue JF Breton, 34093, Montpellier, Cedex 5, France \\ 3 Universidade Federal do Sul e Sudeste do Pará, Av. dos Ipês, s/n, Cidade Jardim, 68500-000 Marabá, Pará, Brazil \\ * Corresponding author: izildinha.miranda@ufra.edu.br; (D) https://orcid.org/0000-0002-2080-3404
}

\section{ABSTRACT}

Shade-tolerant forest species are among the most susceptible to habitat loss in agricultural mosaics, where a variety of croplands is connected to forests at different levels of anthropogenic disturbance. We aimed to evaluate the community similarity of shade-tolerant species among different land use types across agricultural mosaics with different levels of disturbance. The study was conducted in three municipalities in southern and southeastern Pará state, in eastern Amazonia. A multiple-community similarity measure based on the Horn similarity index was used to compare land use types and assess the resilience of shadetolerant species towards forest loss and disturbance at the landscape level. High shade-tolerant species similarity was found between mature forest fragments that underwent different levels of disturbance in all three agricultural mosaics, but secondary forests had lower similarity with mature forest in the most fragmented and altered mosaic. Shade-tolerant species showed very low density in croplands, but the same group of species seemed to colonize agricultural fields of annual crops and clean pasture, as they showed high community similarity. Another group of species was present in invaded pastures, probably due to the effects of time since land abandonment after woody species colonization. Mixed tree plantations were more similar to mature and secondary forests than other types of croplands. Shade-tolerant species similarity was higher among land use types inserted in agricultural landscapes that maintained conserved forest fragments. Our results suggest that the conservation of mature forests and landscape connectivity are crucial to the maintenance of shade-tolerant species in agricultural mosaics.

KEYWORDS: floristics; land use; pasture; resilience; similarity

\section{Potencial de conservação de espécies tolerantes à sombra em mosaicos agrícolas na Amazônia Oriental Brasileira}

\section{RESUMO}

As espécies florestais tolerantes à sombra estão entre as mais suscetíveis à perda de habitat em mosaicos agrícolas, onde uma variedade de terras agrícolas está conectada a florestas em diferentes níveis de distúrbio antropogênico. Este trabalho teve como objetivo avaliar a similaridade da comunidade de espécies tolerantes à sombra entre diferentes tipos de uso da terra em mosaicos agrícolas com diferentes níveis de perturbação. O estudo foi realizado em três municípios localizados no sul e sudeste do estado do Pará. Uma medida de similaridade de comunidade múltipla baseada no índice de similaridade de Horn foi usada para comparar diferentes tipos de uso da terra em três diferentes mosaicos. Alta similaridade de espécies tolerantes à sombra foi encontrada entre fragmentos de florestas maduras que sofreram diferentes níveis de distúrbio nos três mosaicos agrícolas, mas florestas secundárias apresentaram menor semelhança com a floresta madura no mosaico mais fragmentado e alterado. As espécies tolerantes à sombra apresentaram densidades muito baixas nas terras agrícolas, no entanto, o mesmo grupo de espécies tolerantes à sombra parece colonizar os cultivos anuais e as pastagens limpas. Por outro lado, outro grupo de espécies esteve presente em pastagens invadidas. As plantaçôes mistas de árvores foram mais semelhantes às florestas maduras e secundárias do que outros tipos de terras agrícolas. Nossos resultados sugerem que a conservação de florestas maduras e da conectividade da paisagem são cruciais para a manutenção de espécies tolerantes à sombra em mosaicos agrícolas.

PALAVRAS-CHAVE: florística; pastagem; resiliência; similaridade; uso da terra 


\section{INTRODUCTION}

Land use change has been considered as the main cause of global biodiversity loss (Newbold et al. 2015; Barlow et al. 2016). Many of the remaining forest fragments are embedded in landscapes that contain different types of land use, forming an agricultural mosaic, where a variety of croplands is connected to forests at different levels of anthropogenic disturbance (Do Vale et al. 2018).

In these agricultural mosaics, shade-tolerant forest species are most susceptible to natural and anthropogenic forest disturbances. These species have seeds that can germinate and establish in the forest understory (Swaine and Whitmore 1988). Their young individuals are thus commonly found beneath the forest canopy, but can occasionally be seen in open areas (Mitja et al. 2008), while adults can also be seen in agricultural fields, usually as remnants of the forests (Santos and Mitja 2011).

Open environmental conditions, competition with pioneer herbaceous species, absence of animals that disperse seeds, and disturbances during soil preparation for planting crops contribute to the loss of shade-tolerant species (Hooper et al. 2005; Esquivel et al. 2008). This species impoverishment in agricultural mosaics can result in profound consequences for forest restoration, such as erosion of diversity and shifts in the functional composition of forests in anthropogenic landscapes, and provision of forest ecosystem services (Da Silva and Tabarelli 2000; Van Breugel et al. 2013).

An approach to determine the conservation potential of shade-tolerant forest species in agricultural mosaics is the use of measures of species similarity as tools for describing changes in species composition along environmental gradients (Jost et al. 2011). In this sense, land use types can be compared to assess the resilience of shade-tolerant species towards forest loss and disturbance at the landscape level. The similarity between mature forests and forests that have undergone different levels of human disturbance reveals the conservation capacity of these habitats. On one hand, high similarity between mature forests and secondary forests indicates a successional process in the latter towards a greater dominance of late shade-tolerant species. On the other hand, high similarity between secondary forests and agricultural crops can be perceived as a delay in the floristic change over processes that are intrinsic to the forest succession (Do Vale et al. 2018).

Finally, although croplands may be different regarding the species that were planted and land preparation, or even land in degradation stage (e.g., clean and invaded pastures), high similarity of shade-tolerant species between croplands may indicate that these environments are a favorable habitat for a group of late succession species that can survive in open areas. This work aimed to evaluate the community similarity of shade-tolerant species among different land-use types across agricultural mosaics with different levels of disturbance. We hypothesized that highly fragmented landscapes, with lower forest cover, present less similarity in shade-tolerant species between land-use types due to limitation in forest propagule dispersion. Additionally, we evaluated which shade-tolerant forest species were the most resilient to forest habitat loss within agricultural mosaics.

\section{MATERIAL AND METHODS}

\section{Study Area}

The study was conducted in 2008 at three rural communities with small family farms in the settlements of Palmares II, Maçaranduba and Travessáo 338S, located in the municipalities of Parauapebas, Nova Ipixuna and Pacajá, respectively (Figure 1). Each community was considered as an agricultural mosaic where forest fragments are adjacent to different plantations. The communities are located in southern and southeastern Pará State, in the eastern Brazilian Amazon, in the region known as the Arc of Deforestation, where loss of biodiversity is intense, driven by changes in land use caused by deforestation for agriculture (Fearnside 2017). In addition, anthropogenic fires and severe drought events in the last decade also drive floristic and structural changes in the region and contribute to deforestation itself (Morandi et al. 2016).

The dominant primary vegetation is tropical rain forest, and the average annual temperature in the study area is approximately $26^{\circ} \mathrm{C}$. The climate is classified as super humid in Parauapebas, humid tropical in Pacajá and rainy tropical in Nova Ipixuna, according to the Köppen classification.

The Palmares II Settlement Project (05'51'22.2”-05'56'27.4”S, 4952'06”-5003'57.4”W) was established in 1996 with farms of average 86 ha (Figure 1). The settlement is the most fragmented of the three agricultural landscapes, with many pastures and croplands, in addition to the occurence of recent ground fires in remaining forest areas. In Palmares II, unlike in the other two communities, farmers live in a village about $25 \mathrm{~km}$ distant from the agricultural fields, so more access roads and trails were opened, which helps to explain the greater degree of human impact on this area compared to the other two (Oszwald et al. 2011).

The community of Maçaranduba (04045'45.1"-04048'50.1"S, 49 $\left.19^{\circ} 13^{\prime \prime}-49^{\circ} 22^{\prime} 50.2^{\prime \prime} \mathrm{W}\right)$ is located in the Praia Alta-Piranheiras Agricultural-Extractivist Settlement Project (Figure 1). This community was established in 1994 and farms average 71 ha. The landscape had a notably marked dynamic between 1997 and 2004, when 60\% of changes in land use types occurred. The landscape mosaic is composed of pastures at different stages of evolution. The only surviving forest areas are secondary forests formed after cropland abandonment (more than 10 years old), riparian forest or forest fragments in areas of difficult access (Oszwald et al. 2011). 


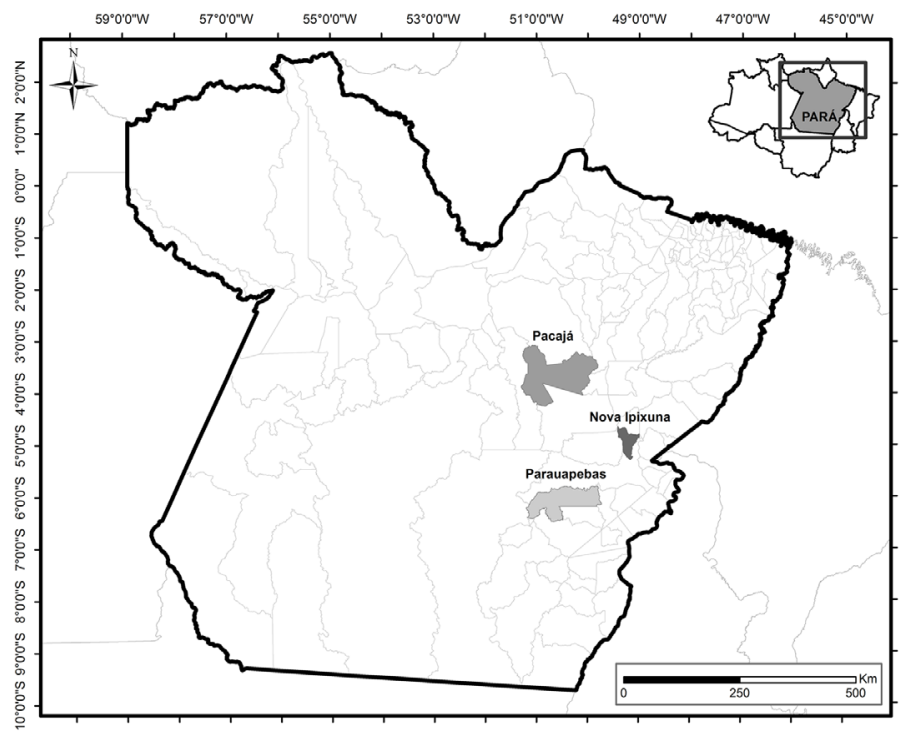

Figure 1. Location of the municipalities Parauapebas, Nova Ipixuna and Pacajá, in the State of Pará, in the eastern Brazilian Amazon, where the three agricultural mosaics were inventoried in the communities of Palmares II, Maçaranduba and Travessão 338S, respectively. The incept shows the position of Pará in northern Brazil.

The community of Travessão $338 \mathrm{~S}$ ( $03^{\circ} 41^{\prime} 52^{\prime \prime}-03^{\circ} 46^{\prime} 48^{\prime \prime} \mathrm{S}$, $\left.51^{\circ} 02^{\prime} 04.7^{\prime \prime}-51^{\circ} 03^{\prime} 28^{\prime \prime} \mathrm{W}\right)$ is located along the TransAmazonian Highway (Figure 1). It was established in 2001 with farms of 26 ha. This area was the most recently affected by deforestation, and is still largely covered by a matrix of primary forest and large forest patches (Oszwald et al. 2011).

\section{Sampling design}

A socio-economic survey carried out with 50 small family farmers helped define which farms were most representative of each agricultural mosaic (De Sartre 2011). Nine representative farms were selected within each mosaic. Five sampling points were established at each farm for the inventory of vegetation, resulting in 45 sampling points per mosaic. The points were equally spaced along the longest diagonal of the farm, thus the distance between the points varied according to the farm size (from about 200 to $400 \mathrm{~m}$ ). Because the points were systematically spaced along the diagonal of each farm, they were not selected based on the type of land use. Thus, it was assumed that the vegetation cover at each sampling point reflected the land use types prevailing in each mosaic, which resulted in a heterogeneous number of sampling points per land use type for each mosaic (Table 1).

Nine types of land use were identified in the three studied agicultural mosaics. The Palmares II mosaic is the only one that has mature burned forest, does not have mature conserved forest and has the largest number of annual crops. Maçaranduba has the largest area of pastures, while Travessão $338 \mathrm{~S}$ has the largest area of mature forest and is the only one with mixed tree plantations (Table 1).

At each sampling point, the vegetation was sampled across three strata. A plot of $10 \times 50 \mathrm{~m}\left(500 \mathrm{~m}^{2}\right)$ was established for the upper stratum inventory, composed by individuals with diameter at breast height $(\mathrm{DBH}) \geq 10 \mathrm{~cm}$. A subplot of $5 \times$ $50 \mathrm{~m}$ was established for the middle stratum, composed by individuals with $\mathrm{DBH}<10 \mathrm{~cm}$ and height $\geq 2 \mathrm{~m}$. Finally, 10 subplots of $1 \times 1 \mathrm{~m}$ were regularly distributed in the center of the plot for the lower stratum inventory, composed by individuals with $2 \mathrm{~m}>$ height $\geq 10 \mathrm{~cm}$.

The species were classified into groups based on their life form (herb, liana, shrub, palm or tree), and their shade tolerance guild (pioneer or shade-tolerant) according to Mitja et al. (2008). Previous species identification was performed by a parataxonomist and was confirmed by comparison with specimens in the Herbarium João Murça Pires at the Museum Paraense Emilio Goeldi. The plants were classified in accordance with the Angiosperm Phylogeny Group III system. The few unidentified individuals $(2,5$ and $6 \%$ of the individuals from Palmares II, Maçaranduba and Travessão 338S, respectively) were excluded from the analysis.

\section{Statistical analysis}

In order to highlight the forest species that survive in the different land use types at agricultural mosaics, floristic analysis was carried out using only the floristic composition of the shade-tolerant species, in which the pioneer species were excluded.

A multiple-community similarity measure based on the Horn similarity index (Horn 1966), modified according to Chao et al. (2008), was used to determine the floristic similarity between land use types within each mosaic. The Horn index weighs species by their abundance, which is more appropriate when rare species are important, as in conservation applications (Jost et al. 2011). To calculate the Horn index, 
Table 1. Number of sampling points per land-use type in three agricultural mosaics (PII = Palmares II, M = Maçaranduba, T338S = Travessão 338S) studied in the "Arc of Deforestation" region, Pará state, Brazil.

\begin{tabular}{|c|c|c|c|c|c|c|}
\hline \multirow{2}{*}{ Acronym } & \multirow{2}{*}{ Land-use type } & \multirow{2}{*}{ Description } & \multicolumn{3}{|c|}{ Agricultural mosaics } & \multirow{2}{*}{ Tota } \\
\hline & & & PII & MAÇ & T338 & \\
\hline ConFor & Mature conserved forests & $\begin{array}{l}\text { Forests with a well-defined vertical structure and no signs of recent } \\
\text { human disturbance. (three vertical strata) }\end{array}$ & - & 8 & 7 & 15 \\
\hline ExpFor & Mature exploited forests & $\begin{array}{l}\text { Forests showing signs of disturbance, such as clearings resulting from } \\
\text { timber extraction. (three vertical strata) }\end{array}$ & 5 & 3 & 16 & 24 \\
\hline BunrFor & Mature burned forests & Forests showing signs of fire. (three vertical strata) & 10 & - & - & 10 \\
\hline OldSec & Old secondary forest & $\begin{array}{l}\text { Secondary forests with a defined woody upper canopy, older than } 12 \\
\text { years. (three vertical strata) }\end{array}$ & 3 & 9 & 4 & 16 \\
\hline YoungSec & Young secondary forest & $\begin{array}{l}\text { Secondary forests lacking a defined upper woody stratum, younger than } \\
12 \text { years old. (two vertical strata) }\end{array}$ & 6 & 4 & 5 & 15 \\
\hline InvPas & Invaded pastures ${ }^{a}$ & $\begin{array}{l}\text { Pastures with a high abundance of herbaceous individuals and young } \\
\text { seedlings of woody species. (two vertical strata) }\end{array}$ & 4 & 11 & 6 & 21 \\
\hline ClePas & Clean pastures ${ }^{\mathrm{a}}$ & Pastures with a low density of woody species. (two vertical strata) & 7 & 9 & 1 & 17 \\
\hline AnnCrop & Annual crops & $\begin{array}{l}\text { Rice (Oryza sp.), bean (Vigna sp.), corn (Zea mays) and especially cassava } \\
\text { (Manihot esculenta) plantations. (two vertical strata) }\end{array}$ & 10 & 1 & 2 & 13 \\
\hline MixTree & Mixed tree plantation ${ }^{\mathrm{b}}$ & $\begin{array}{l}\text { Cocoa (Theobroma cacao) plantations generally combined with paricá } \\
\text { (Schizolobium amazonicum) (two vertical strata) }\end{array}$ & - & - & 4 & 4 \\
\hline \multicolumn{3}{|c|}{ Total sampling points } & 45 & 45 & 45 & 135 \\
\hline
\end{tabular}

a Urochloa brizantha was the predominant forage plant in Maçaranduba and Palmares II, while Urochloa decumbens predominated in Travessão $338 \mathrm{~S}$.

${ }^{\mathrm{b}}$ Mixed tree plantations are uncommon in southeastern Pará and were restricted to Travessão 338S, which is part of the cocoa-producing region in southern Pará

we first extrapolated the abundance of each species in the lower and medium stratum to the larger area of the upper stratum $\left(500 \mathrm{~m}^{2}\right)$ in order to standardize abundance among strata by plot, and divided the abundance by the number of sampling points on each land use type (Table 1). Finally, we summed the abundance of the three strata to eliminate the stratification at each sampling point. The mean abundance of the sampling points of each land use type was used to calculate the Horn index. Horn index (h) varies from 0 to 1, for minimum and maximum similarity, respectively. To compare the community similarity among land-use types, the index values were categorized in very low similarity $(\mathrm{h}<0.2)$, low similarity $(0.2 \leq \mathrm{h}<0.4)$, medium similarity $(0.4 \leq \mathrm{h}<$ $0.6)$, high similarity $(0.6 \leq \mathrm{h}<0.8)$ and very high similarity (h $\geq 0.8$ ). Analyses were performed with the R-Studio interface for R Core Team (2019) using the SimilarityMult function of the SpadeR package, which compares the similarity between more than two communities (land use types) simultaneously, considering the species shared by all the communities.

\section{RESULTS}

In total, we found 1298 species across all mosaics and land use types, of which 968 were classified as shade-tolerant. Forests generally showed a higher total number of species, as well as a higher relative richness and relative abundance of shade-tolerant species when compared to croplands (Table 2). The land use types where we found highest proportions of shade-tolerant species were exploited forests at Palmares II and conserved forests at Maçaranduba (84\% of the species and $90 \%$ of the individuals) and Travessão 338 (89\% of the species and $95 \%$ of the individuals). Even though some croplands showed a relatively high total frequency of shadetolerant species per plot (e.g., annual crops in Palmares II - 57\%; mixed tree plantations in Travessão $338-56 \%$ ), the total relative abundance of shade-tolerant species per plot was low, varying from $4 \%$ in clean pastures at Maçaranduba to $48 \%$ in mixed tree plantations at Travessão 338. Most of the individuals in those cropland types belonged to non-shade tolerant species (Table 2).

No case of very high similarity between land use types was recorded, and only four cases of high similarity were observed (Figure 2). At Palmares II, the predominance was of low or very low similarity among the types of uses, except between exploited and burned forests $(h=0.6)$, clean pastures and annual crops $(\mathrm{h}=0.71)$, and annual crop and young secondary forest $(h=0.53)$ (Figure 2$)$. At Maçaranduba only mature forests showed high similarity $(h=0.64)$, old and young secondary forests showed medium similarity with conserved and exploited forest, and clean and invaded pastures showed low or very low similarity with all other uses (Figure 2). At Travessão 338S, as in the other mosaics, only mature forests showed high similarity $(h=0.72$ ), old secondary forests and mixed tree plantation showed medium similarity with mature 
Table 2. Number of species per land-use type in three agricultural mosaics in the "Arc of Deforestation"region, Pará state, Brazil. Values are the average, standard deviation (SD), minimum (Min) and maximum (Max) number of species per plot, total (Total) number of species per land-use type and overall percentage of shadetolerant species and individuals.

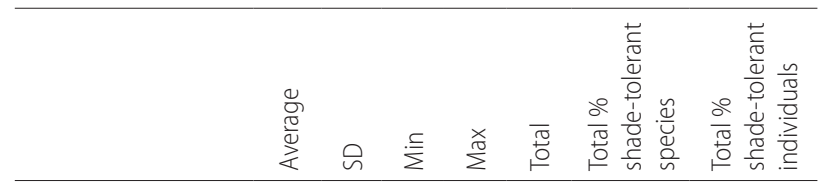

\begin{tabular}{|c|c|c|c|c|c|c|c|}
\hline Palmares II & & & & & & & \\
\hline Exploited forest & 60 & 13 & 42 & 78 & 229 & 84 & 90 \\
\hline Burned Forest & 47 & 19 & 17 & 84 & 303 & 78 & 70 \\
\hline Old secondary forest & 27 & 7 & 19 & 32 & 87 & 64 & 41 \\
\hline $\begin{array}{l}\text { Young secondary } \\
\text { forest }\end{array}$ & 23 & 11 & 11 & 35 & 154 & 56 & 37 \\
\hline Annual Crop & 15 & 3 & 10 & 20 & 156 & 57 & 33 \\
\hline Invaded pastures & 19 & 8 & 9 & 29 & 111 & 53 & 18 \\
\hline Clean pastures & 25 & 23 & 9 & 59 & 78 & 45 & 15 \\
\hline
\end{tabular}

Maçaranduba

\begin{tabular}{lccccccc} 
Conserved forest & 59 & 10 & 43 & 72 & 272 & 86 & 92 \\
Exploited forest & 67 & 7 & 59 & 72 & 170 & 87 & 88 \\
Old secondary forest & 44 & 18 & 16 & 70 & 298 & 79 & 75 \\
$\begin{array}{l}\text { Young secondary } \\
\text { forest }\end{array}$ & 21 & 12 & 3 & 28 & 121 & 60 & 52 \\
Invaded pastures & 7 & 5 & 0 & 16 & 143 & 47 & 12 \\
Clean pastures & 3 & 2 & 1 & 6 & 74 & 28 & 4 \\
\hline
\end{tabular}

Travessão 338

\begin{tabular}{lccccccc} 
Conserved forest & 58 & 10 & 50 & 78 & 255 & 89 & 95 \\
Exploited forest & 60 & 38 & 36 & 228 & 446 & 87 & 93 \\
Old secondary forest & 49 & 10 & 36 & 58 & 176 & 87 & 94 \\
$\begin{array}{l}\text { Young secondary } \\
\text { forest }\end{array}$ & 28 & 5 & 22 & 33 & 147 & 72 & 42 \\
$\begin{array}{l}\text { Mixed tree plantation } \\
22\end{array}$ & 7 & 13 & 30 & 130 & 56 & 48 \\
\hline Invaded pastures & 7 & 7 & 1 & 18 & 69 & 48 & 7
\end{tabular}

forests, and the invaded pastures showed low or very low similarity with all others uses (Figure 2).

Shade-tolerant forest trees and palms represented a very low percentage of the relative abundance in croplands, with no species higher than $0.5 \%$. Attalea speciosa Mart. ex Spreng. (0.49\%), Geissospermum vellosii Allemão (0.12\%), Annona exsucca DC. (0.35\%) and Tabernaemontana macrocalyx Müll. Arg. (0.14\%) showed higher relative abundanc in mixed tree plantations, annual crops, invaded and clean pastures, respectively. Theobroma cacao L. had $1.11 \%$ relative abundance, but is considered as natural regeneration of the individuals planted in the mixed tree plantations (Table 3).

Palmares II
Exploited forest
Burned forest
Old secondary forest
Young sec. forest
Annual crop
Invaded pasture
Clean pasture

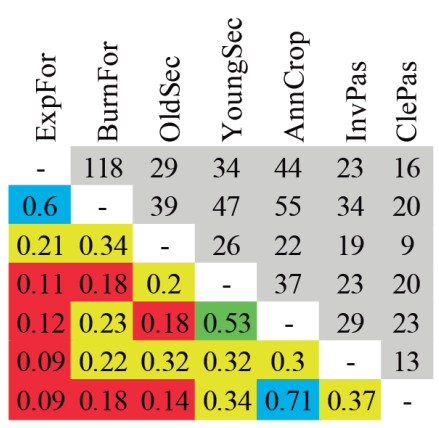

Maçaranduba

Conserved forest Exploited forest Old secondary forest Young sec. forest Invaded pasture Clean pasture

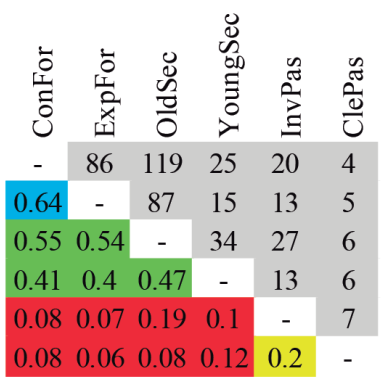

Travessão 338S

Conserved forest

Exploited forest

Old secondary forest

Young sec. forest

Mixed tree plantation

Invaded pasture

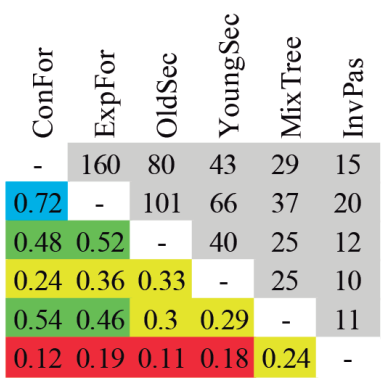

Figure 2. Horn similarity index of shade-tolerant species (coloured according to the Horn similarity index value range) and number of shared species (in gray) between land use types in the agricultural mosaics of Palmares II, Maçaranduba and Travessão $338 \mathrm{~S}$ (Pará, Brazil). Land-use acronyms: ConFor = mature conserved forest; ExpFor = mature exploited forest; BunrFor = mature burned forest; OldSec = old secondary forest; YoungSec = young secondary forest; InvPas = invaded pasture; $\mathrm{ClePas}=$ clean pasture; $\mathrm{AnnCrop}=$ annual $\mathrm{crops} ;$ MixTree = mixed tree plantation. This figure is in color in the electronic version.

Among all shade-tolerant species (including trees, palms, shrubs and herbs), 10 at Travessão $338 \mathrm{~S}$ and four at Maçaranduba were present in all or five of the six land-use types within each mosaic, and four species were present in all or six of the seven land-use types present at Palmares II. The species with the highest incidence among land-use types were Heliconia hirsuta L.f., present in all land-use types at Palmares II, Gustavia augusta L., present in all land-use types at Maçaranduba, and Astrocaryum gynacanthum Mart., Attalea 
maripa (Aubl.) Mart.and Attalea speciosa, present in all landuse types at Travessão 338S. Astrocaryum gynacanthum also had high incidence at Palmares II and Maçaranduba, and Gustavia augusta at Maçaranduba and Travessão 338 S (Figure 3).

\section{DISCUSSION}

Among the three agricultural mosaics, Maçaranduba and Travessão $338 \mathrm{~S}$ were the only ones that had conserved mature forest areas without recent signs of human disturbance. The

Table 3. Relative abundance (\%) of most abundant shade-tolerant trees and palms in croplands in three agricultural mosaics in the "Arc of Deforestation" region, Pará state, Brazil. Highest scores of relative abundance in each land-use type are in bold. Land-use acronyms: ConFor = mature conserved forest; ExpFor = mature exploited forest; BunrFor = mature burned forest; OldSec = old secondary forest; YoungSec = young secondary forest; InvPas = invaded pasture; ClePas = clean pasture; AnnCrop $=$ annual crops; MixTree $=$ mixed tree plantation.

\begin{tabular}{|c|c|c|c|c|c|c|c|c|}
\hline \multirow{2}{*}{ Species } & \multirow{2}{*}{ Life form } & \multicolumn{3}{|c|}{ Palmares II } & \multicolumn{2}{|c|}{ Maçaranduba } & \multicolumn{2}{|c|}{ Travessão 338S } \\
\hline & & AnnCrop & InvPas & ClePas & InvPas & ClePas & MixTree & InvPas \\
\hline Alexa grandiflora & Tree & 0.001 & 0.33 & 0 & 0.002 & 0 & 0 & 0 \\
\hline Annona exsucca & Tree & 0.06 & 0.35 & 0 & 0 & 0 & 0.005 & 0 \\
\hline Astrocaryum gynacanthum & Palm & 0.09 & 0.003 & 0 & 0.12 & 0 & 0.14 & 0.008 \\
\hline Attalea speciosa & Palm & 0 & 0 & 0 & 0.005 & 0 & 0.49 & 0.05 \\
\hline Enterolobium shomburgkii & Tree & 0 & 0 & 0.07 & 0 & 0 & 0 & 0 \\
\hline Eugenia patrisii & Tree & 0 & 0 & 0 & 0.3 & 0 & 0 & 0 \\
\hline Geissospermum vellosii & Tree & 0.12 & 0.33 & 0.07 & 0 & 0 & 0 & 0 \\
\hline Gustavia augusta & Tree & 0 & 0 & 0 & 0.06 & 0.06 & 0.02 & 0 \\
\hline Handroanthus serratifolius & Tree & 0 & 0 & 0 & 0.3 & 0 & 0 & 0 \\
\hline Jacaranda copaia & Tree & 0 & 0 & 0 & 0 & 0.13 & 0.04 & 0 \\
\hline Ocotea cernua & Tree & 0 & 0 & 0 & 0 & 0 & 0.27 & 0 \\
\hline Pachira aquatica & Tree & 0 & 0 & 0 & 0 & 0.06 & 0 & 0 \\
\hline Protium sagotianum & Tree & 0 & 0 & 0 & 0 & 0 & 0 & 0.1 \\
\hline Rinorea neglecta & Tree & 0 & 0 & 0 & 0 & 0 & 0 & 0.1 \\
\hline Senna georgica & Tree & 0.09 & 0 & 0 & 0 & 0 & 0 & 0 \\
\hline Siparuna guianensis & Tree & 0 & 0 & 0 & 0.18 & 0 & 0 & 0 \\
\hline Tabernaemontana macrocalyx & Tree & 0 & 0 & 0.14 & 0 & 0 & 0 & 0 \\
\hline Theobroma cacao & Tree & 0 & 0 & 0 & 0 & 0 & 1.11 & 0 \\
\hline Trichilia sp. & Tree & 0 & 0 & 0 & 0 & 0 & 0 & 0.2 \\
\hline
\end{tabular}

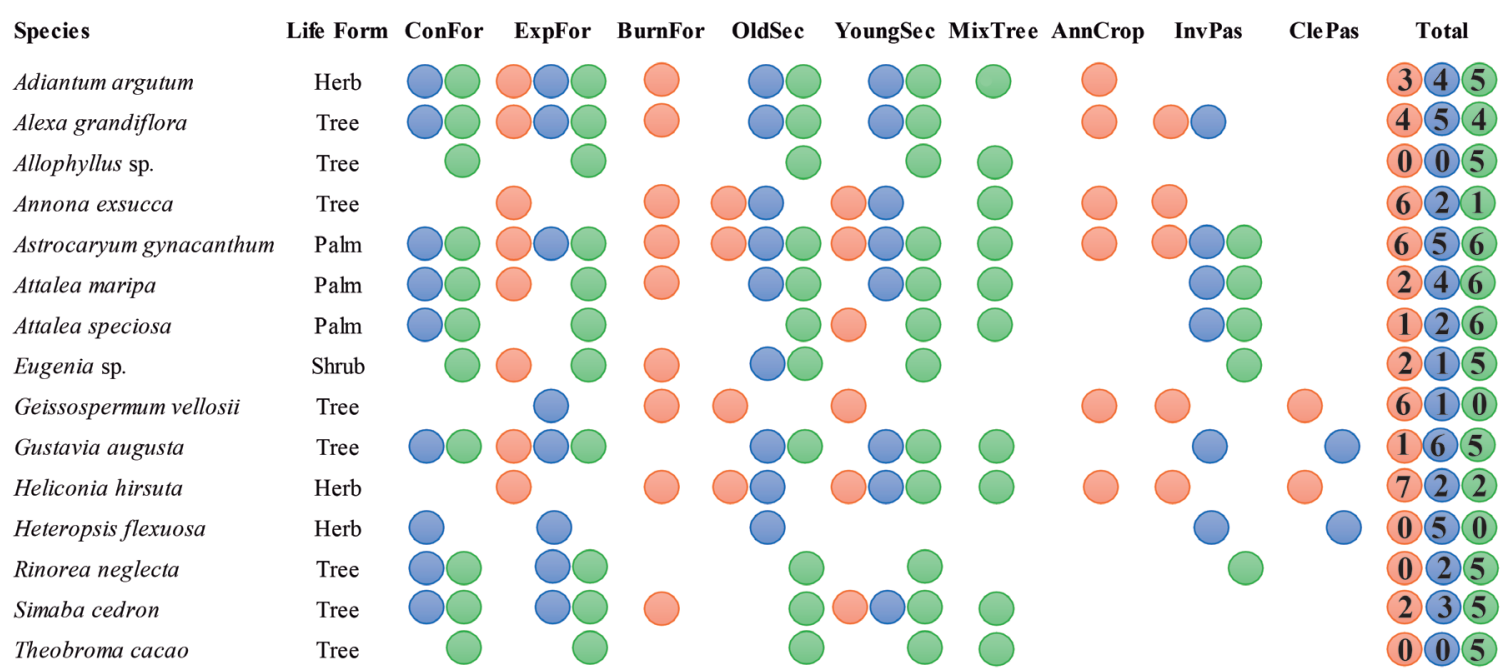

Figure 3. Number of land-use types in which most incident shade-tolerant forest species were present in the agricultural mosaics of Palmares $I I$, Maçaranduba and Travessão $338 \mathrm{~S}$ (Pará, Brazil). Land-use acronyms: ConFor = mature conserved forest; ExpFor = mature exploited forest; BunrFor = mature burned forest; OldSec = old secondary forest; YoungSec = young secondary forest; InvPas = invaded pasture; ClePas = clean pasture; AnnCrop = annual crops; MixTree = mixed tree plantation. This figure is in color in the electronic version. 
high similarity of these conserved forests with exploited forests indicates a high maintenance capacity of shade-tolerant species in the forest fragments of the agricultural mosaics, even after selective cutting. Indeed, selective logging has been considered a disturbance that can maintain high rates of forest richness, even though there is a biodiversity-reducing effect, but much lower when compared to other types of human disturbance (Gibson et al. 2011).

The same level of conservation could not be confirmed at Palmares II, as all of its forest fragments were disturbed. Additionally, exploited forests at Palmares II were highly similar with burned forests, which were expected to present the highest reduction in biodiversity, since plants are the biological group most sensitive to fire (Gibson et al. 2011) (although fire intensity and frequency influences the extent of the disturbance). This result may imply a higher level of impact of logging on biodiversity in already fragmented and disturbed landscapes. Disturbances within the forest fragments, when combined with disturbances of a highly degraded landscape, result in greater negative effects on biodiversity, especially on species of high conservation value and functionality (Barlow et al. 2016). The negative effects on biodiversity conservation at Palmares II were also suggested by the low or very low similarity between the disturbed mature forests and secondary forests, which indicates a delay in the progression of forest succession, probably caused by a functionally reduced speciesrich forest cover in the landscape (Van Breugel et al. 2013; Do Vale et al. 2018).

Conservation of mature forests and species-rich secondary forests is crucial for biodiversity in tropical human-disturbed landscapes (Vieira and Proctor 2007; Rozendaal et al. 2019), since it can accelerate forest succession by providing nondegraded soils, abundant sources of propagules for plant regeneration, seeds, soil seed bank, seedling bank and sprouts, as well as reduced filtering imposed by site conditions, edge effects and resource exploitation by human populations (Arroyo-Rodríguez et al. 2017). At Maçaranduba and Travessão 338S, medium similarity between mature forests and old secondary forests points to a greater landscape connectivity in these mosaics, and, therefore, greater conservation potential. It also demonstrates that old secondary forests can maintain high richness and abundance of shade-tolerant species, playing an important role for conservation, particularly when landscapes present higher forest cover, low intensity of previous land use and presence of more conserved forests.

Presence of shade-tolerant forest species in agricultural land-use types was lower in both active and abandoned crops. At Palmares II, high similarity between annual crops and clean pastures revealed a favorable habitat for a group of shadetolerant forest species that can persist in both environments. However, environmental heterogeneity established between invaded and clean pastures favored different arrays of forest species. The difference between types of pastures is probably due to time since abandonment of the invaded pastures, where previous woody species colonization can cause additional positive effects on future natural regeneration (Rocha et al. 2016). Despite this invasion, adjacent forest cover seems to have limited influence on these land use types, as shown by the overall low similarity between invaded pastures and the forest land-use types. This is probably due to the limited range of animal dispersers in open environments, and also because invaded pastures - in spite of their woody component - have very different environmental conditions than surrounding forests, restricting the establishment of many shade-tolerant species even among those that are able to arrive (Letcher and Chazdon 2009; Rocha et al. 2016).

In contrast, mixed tree plantations showed medium similarity with old secondary forests at Travessão 338S, which was expected, since annual crops and pastures have greater negative impact on biodiversity than agroforestry systems and shaded plantations (Gibson et al. 2011). Mixed plantations of native trees generally promote more adequate environmental conditions for shade-tolerant forest species, such as the establishment of a more favorable microclimate, higher concentration of organic matter, lesser soil erosion and higher attraction of dispersing agents (Akoto et al. 2015; Zermeño-Hernández et al. 2015).

Although agricultural mosaics can provide important habitat and foraging sites for forest species, as well as stepping stones and corridors for biotic dispersal and animal migration, managed croplands have typically a lower biodiversity value than more complex environments, such as secondary forests and mixed plantations (Laurance et al. 2014; Do Vale et al. 2017). However, shade-tolerant forest species that can maintain a minimum density in croplands can be used for forest restoration, as they improve seed dispersal, attracting animal dispersers and improving seed rain and the seed bank, and provide a more favorable microclimate for the establishment of seedlings and shade herbaceous species (Holl et al. 2000; Stanturf et al. 2014).

Among trees that were present in the studied croplands, we can highlight Alexa grandiflora Ducke, Annona exsucca, Geissospermum vellosii, Gustavia augusta and Rinorea neglecta Sandwith, which were the most representative in density and incidence in one or more croplands at the agricultural mosaics. However, insufficient knowledge of the collection, storage, germination and nursery cultivation requirements of these species may presently limit their potential use in forest restoration management programs (Hooper et al. 2005).

The importance of palm trees in croplands must also be underlined. Astrocaryum gynacanthum, Attalea maripa and Attalea speciosa were some of the most dense and incident species at the mosaics. They have a great capacity for colonization and are commonly found in other open areas of 
southeastern Pará State, where this study was conducted (Salm et al. 2005; Santos and Mitja 2011). They have large seeds and are moderately to highly shade-tolerant, attributes that are recommended for species to be used in forest restoration (Hooper et al. 2002). Moreover, these palm trees are resistant to the slash-and-burn cultivation system used in family farming (Mitja et al. 2008, 2017; Santos and Mitja 2011). Fire can stimulate the germination of seeds that were buried in the soil by grazing (Shanley and Medina 2005). These palms can grow and reproduce faster after disturbing events, because their columnar architecture provides advantages in competition with ephemeral pioneers such as lianas, which can facilitate the restoration in height and density of the secondary forest canopy (Salm et al. 2005).

\section{CONCLUSIONS}

Agricultural mosaics can maintain high conservation potential of shade-tolerant species in forest fragments that have undergone different levels of disturbance. This potential is higher in mature forests, even if they were exploited. However, the conservation potential of shade-tolerant species was lower in secondary forests found at the most fragmented and humandisturbed mosaic. This suggests that the conservation of mature forests and the maintenance of landscape connectivity is crucial to the maintenance of shade-tolerant species in forest fragments across the landscape. Shade-tolerant forest species showed very low densities in croplands, but a similar assemblage seemed to colonize annual crops and clean pastures, while in invaded pastures other species were present. To consider the difference between croplands is a step further to improve species selection for forest restoration. There is also a need for research in cultivation and implementation requirements of these species, since most have little or no information related to its silvicuture.

\section{ACKNOWLEDGMENTS}

This research was funded by Agence Nationale de la Recherche (France) through grants ANR-06-PADD-001-011 (Agriculture Durable et Développement program) and ANR 06 BIODIV 009-01 (IFB-ANR), and by Conselho Nacional de Desenvolvimento Científico e Tecnológico - CNPq (Brazil) through INCT Biodiversidade e Uso do Solo na Amazônia. CNPq provided a scholarship to Igor Do Vale. We thank the farmers of the Maçaranduba, Palmares II and Travessão 338sul communities for their help, availability and conviviality during fieldwork, and Mr. Deurival da Costa Carvalho for his efficiency and enthusiasm during fieldwork. We also thank Livia Teixeira, Luciana Brabo, Helber Shibata, Fábio Leấo, Joice Silva, José Moreira, Heraldo Silva, Robson Ramos and Magno Reis for their help in fieldwork.

\section{REFERENCES}

Akoto, S.D.; Asare, A.; Gyabaa, G. 2015. Natural regeneration, diversity and composition of native tree species under monoculture, mixed-culture plantation and natural forest. International Research Journal of Natural Sciences, 3: 24-38.

Arroyo-Rodríguez, V.; Melo, F.P.; Martínez-Ramos, M.; Bongers, F.; Chazdon, R.L.; Meave, J.A.; et al. 2017. Multiple successional pathways in human-modified tropical landscapes: new insights from forest succession, forest fragmentation and landscape ecology research. Biological Reviews, 92: 326-340.

Barlow, J.; Lennox, G.D.; Ferreira, J.; Berenguer, E.; Lees, A.C.; Mac Nally, R.; et al. 2016. Anthropogenic disturbance in tropical forests can double biodiversity loss from deforestation. Nature, 535: 144-147.

Chao, A.; Chazdon, R.L.; Colwell, R.K.; Shen, T.J. 2005. A new statistical approach for assessing similarity of species composition with incidence and abundance data. Ecology Letters, 8: 148-159.

Chao, A.; Jost, L.; Chiang, S.C.; Jiang, Y.H.; Chazdon, R.L. 2008. A two-stage probabilistic approach to multiple-community similarity indices. Biometrics, 64: 1178-1186.

Da Silva, J.M.C.; Tabarelli, M. 2000. Tree species impoverishment and the future flora of the Atlantic forest of northeast Brazil. Nature, 404: 72-74.

De Sartre, X.A.; Oszwald, J.; Ramírez, B.; Rodríguez, G.; Velazquez, J.; Sebille, P.; Lavelle, P. 2011. Caractéristiques socio-économiques d'une intégration régionale em Amazonie colombienne (région de Florencia, Caqueta). Caravelle, 96: 91-110.

Do Vale, I.; Miranda, I.S.; Mitja, D.; Santos, G.G.A. 2017. Riqueza de plantas em mosaicos rurais na região do arco do desmatamento, Amazônia Oriental, Brasil. Revista Espacios, 38: 1-17.

Do Vale, I.; Miranda, I.S.; Mitja, D.; Santos, A.M.; Lima, T.T.S.; Costa, L.G.S. 2018. Successional processes in agricultural mosaics in the eastern Amazon. Agriculture, Ecosystems and Environment, 256: 51-60.

Esquivel, M.J.; Harvey, C.A.; Finegan, B.; Casanoves, F.; Skarpe, C. 2008. Effects of pasture management on the natural regeneration of neotropical trees. Journal of Applied Ecology, 45: 371-380.

Fearnside, P.M. 2017. Deforestation of the Brazilian Amazon. In: Shugart, H. (Ed.). Oxford Research Encyclopedia, Environmental Science. Oxford University Press, New York, p.1-52. (http:// dx.doi.org/10.1093/acrefore/9780199389414.013.102). Accessed on 21 Jun 2019.

Gibson, L.; Lee, T.M.; Koh, L.P.; Brook, B.W.; Gardner, T.A.; Barlow, J.; et al. 2011. Primary forests are irreplaceable for sustaining tropical biodiversity. Nature, 478: 378-381.

Harnik, P.G.; Simpson, C.; Payne, J.L. 2012. Long-term differences in extinction risk among the seven forms of rarity. Proceedings of the Royal Society B: Biological Sciences, 279: 4969-4976.

Holl, K.D.; Loik, M.E.; Lin, E.H.; Samuels, I.A. (2000). Tropical montane forest restoration in Costa Rica: overcoming barriers to dispersal and establishment. Restoration Ecology, 8: 339-349.

Hooper, E.; Legendre, P.; Condit, R. 2005. Barriers to forest regeneration of de-forested and abandoned land in Panama. Journal of Applied Ecology, 42: 1165-1174. 
Hooper, E.; Condit, R.; Legendre, P. 2002. Responses of 20 native tree species to reforestation strategies for abandoned farmland in Panama. Ecological Applications, 12: 1626-1641.

Horn, H.S. 1966. Measurement of "overlap" in comparative ecological studies. American Naturalist, 100: 419-424

Jost, L.; Chao, A.; Chazdon, R.L. 2011. Compositional similarity and beta diversity. In: Magurran, A.; McGill, B. (Ed.). Biological Diversity: Frontiers in Measurement and Assessment. Oxford University Press, Oxford, p. 66-84.

Kim, D.H.; Sexton, J.O.; Townshend, J.R. 2015. Accelerated deforestation in the humid tropics from the 1990s to the 2000s. Geophysical Research Letters, 42: 3495-3501.

Laurance, W.F.; Sayer, J.; Cassman, K.G. 2014. Agricultural expansion and its impacts on tropical nature. Trends in Ecology and Evolution, 29: 107-116.

Letcher, S.G.; Chazdon, R.L. 2009. Rapid recovery of biomass, species richness, and species composition in a forest chronosequence in northeastern Costa Rica. Biotropica, 41: 608-617.

Mitja, D.; Miranda, I.; Velasquez, E.; Lavelle, P. 2008. Plant species richness and floristic composition change along a rice-pasture sequence in subsistence farms of Brazilian Amazon, influence on the fallows biodiversity (Benfica, State of Pará). Agriculture, Ecosystems and Environment, 124: 72-84.

Mitja, D.; Delaître, E.; Santos, A.M.; Miranda, I.; Coelho, R.F.R.; Macedo, D.J.; Demagistri, L.; Petit, M. 2017. Satellite images combined with field data reveal negative changes in the distribution of babassu palms after clearing off Amazonian forests. Environmental Management, 2: 321-336.

Morandi, P.S.; Marimon, B.S.; Eisenlohr, P.V.; Marimon-Junior, B.H.; Oliveira-Santos, C.; Feldpausch, T.R.; Phillips, O.L. 2016. Patterns of tree species composition at watershed-scale in the Amazon 'arc of deforestation': implications for conservation. Environmental Conservation, 43: 317-326.

Newbold, T.; Hudson, L.N.; Hill, S.L.; Contu, S.; Lysenko, I.; Senior, R.A.; et al. 2015. Global effects of land use on local terrestrial biodiversity. Nature, 520: 45-50.

Newbold, T.; Hudson, L.N.; Arnell, A.P.; Contu, S.; De Palma, A.; Ferrier, S.; et al. 2016. Has land use pushed terrestrial biodiversity beyond the planetary boundary? A global assessment. Science, 353: 288-291.
R Core Team, 2019. R: A language and environment for statistical computing. R Foundation for Statistical Computing, Vienna. (https://www.R-project.org/). Accessed on 21 Jun 2019.

Rocha, G.P.; Vieira, D.L.; Simon, M.F. 2016. Fast natural regeneration in abandoned pastures in southern Amazonia. Forest Ecology and Management, 370: 93-101.

Rozendaal, D.M.; Bongers, F.; Aide, T.M.; Alvarez-Dávila, E.; Ascarrunz, N.; Balvanera, P.; et al. 2019. Biodiversity recovery of Neotropical secondary forests. Science Advances, 5: eaau3114.

Salm, R.; Jalles-Filho, E.; Schuck-Paim, C. 2005. A model for the importance of large arborescent palms in the dynamics of seasonally-dry Amazonian forests. Biota Neotropica, 5: 151-156.

Santos, A.M.D.; Mitja, D. 2011. Wooded cattle pasture in the Benfica Seetling Project in Itupiranga, Pará, Brazil. Revista Árvore, 35: 919-930.

Shanley, P.; Medina, G. (Eds.). 2005. Frutiferas e Plantas Úteis na Vida Amazônica. CIFOR, Belém, 304p.

Stanturf, J.A.; Palik, B.J.; Dumroese, R.K. 2014. Contemporary forest restoration: a review emphasizing function. Forest Ecology and Management, 331: 292-323.

Swaine, M.D.; Whitmore, T.C. 1988. On the definition of ecological species groups in tropical rain forests. Plant Ecology, 75: 81-86.

Van Breugel, M.; Hall, J.S.; Craven, D.; Bailon, M.; Hernandez, A.; Abbene, M.; Van Breugel, P. 2013. Succession of ephemeral secondary forests and their limited role for the conservation of floristic diversity in a human-modified tropical landscape. PloS One, 8: e82433.

Vieira, I.C.G.; Proctor, J. 2007. Mechanisms of plant regeneration during succession after shifting cultivation in eastern Amazonia. Plant Ecology, 192: 303-315.

Zermeño-Hernández, I.; Méndez-Toribio, M.; Siebe, C.; BenítezMalvido, J.; Martínez-Ramos, M. 2015. Ecological disturbance regimes caused by agricultural land uses and their effects on tropical forest regeneration. Applied Vegetation Science, 18: 443-455.

RECEIVED: $11 / 08 / 2019$

ACCEPTED: $15 / 04 / 2020$

ASSOCIATE EDITOR: André B. Junqueira 